\title{
Will Enterprise Ownership Affect the Performance of Foreign Direct Investment? Based on the Perspective of Institutional Logic
}

\author{
Shijuan CUI, Meijie LI and Lingyu LI ${ }^{1}$ \\ College of Management, Shenzhen University
}

\begin{abstract}
In recent years, Chinese enterprises have been developing rapidly with the encouragement of the "Belt and Road" initiative, setting off a new wave of direct investments in foreign. On the stage of global trade competition, one of the biggest differences in companies between Chinese and Western lies in the forms of enterprise ownership. Does enterprise ownership have an impact on the performance of direct investment in foreign? This study takes the inter-provincial panel data of 571 listed companies in China from 2014 to 2017 as a sample. Based on the practices and characteristics of Chinese enterprises' direct investment in foreign, we use a institutional logic perspective to explore the impact of enterprise ownership on performance of the investment. The study found that non-stateowned enterprises perform better in the investment; state-owned enterprises have more resource-seeking Chinese enterprises' foreign direct investment (OFDI), while non-state-owned enterprises tend to choose market-seeking OFDI; marketseeking OFDI has better performance than resource-seeking and technology OFDI performs better. The research proves that the corporate ownership has an impact on the performance of the investment. The conclusions of this paper are helpful to adjust national policies as well as provide a reference for Chinese enterprises in decision marking from institutional perspective.
\end{abstract}

Keywords. Institutional Logic, Enterprise Ownership, OFDI, Enterprise Performance

\section{Introduction}

Will enterprise ownership affect the performance of the enterprise's foreign direct investment? The impact of ownership on enterprises is a key issue in China's strategic research field, because it determines the correct internationalization strategy and the appropriate degree of internationalization, and provides guidance for enterprises on how to choose their own internationalization strategy and global layout. This research is driven by reality. Since the implementation of the "Going Global" strategy in 2001, Chinese enterprises' foreign direct investment (Hereinafter referred to as OFDI) has grown rapidly, and the overall upward trend is obvious, occupying the top three positions in the world for seven consecutive years. An analysis of the characteristics of China's dominant state-owned enterprises and increasingly active private enterprises in

\footnotetext{
${ }^{1}$ Corresponding Author, Mail: lilingyu2019@email.szu.edu.cn.
} 
their outward direct investment behavior will undoubtedly be the entry point for a comprehensive and in-depth understanding of China's outward direct investment.

In the current academic world, there is much room for improvement in terms of sample size, research depth, and breadth. Existing scholars have conducted theoretical and empirical studies on China's OFDI motivation [1], the relationship between the degree of internationalization of enterprises and performance [2], etc., and have achieved certain research results, but it is worth noting that: Some studies have yet to be perfected in terms of research perspectives and measurement indicators of institutional factors.

This article attempts to explore and verify the direct and regulatory mechanism of corporate ownership on the enterprise from the perspective of institutional logic, and how institutional logic affects corporate performance and competitive advantage. By using the perspective of institutional logic to deeply analyze the complex impact of the Chinese context on corporate FDI decisions, it contributes to the academic community.

\section{Institutional logic}

Institutional logic is a research method that emerges at the new stage of new institutionalist theory. It is related to a series of material practices and symbolic structures, driving and constraining the behavior of social actors and shaping behavior [3]. One of the basic assumptions is that different institutional logics will lead to different decisions and behaviors [4].

The current research on China related to institutional logic mainly focuses on the changes in the dominant logic during the "plan-market" transition period. Numerous studies have shown that in China, companies are mainly influenced by the two dominant logics of national logic and market logic [5-9]. National logic and market logic are very different in nature: The goal of national logic is to protect the overall interests of society. It is to emphasize the basic direction of the country in ensuring social and political order, and to create a series of rules and meanings to set up an institutional framework for the environmental behavior of enterprises; The market logic is to form a normative and cultural understanding through property rights arrangements and transactions. All parties to the transaction pursue maximum private benefits through free competition, emphasizing that corporate behavior is mainly driven by their own interests. In the more than 30 years since the reform, through the interaction of different social forces, China has gradually formed a situation in which the two logics of state logic and market logic coexist and influence each other. The historical stage of rapid economic development and rapid system changes has made enterprises often face an extremely complex and changing system environment.

Among state-owned enterprises, the influence of national logic is strong. Xia Lijun and Fang Yiqiang believe that the government has the greatest influence on stateowned enterprises [10]. On the one hand, for enterprises with strong government control, the government has the motivation and ability to internalize the country's overall policies into the controlled enterprises. For example, the government requires enterprises to invest in the country. Due to the scarcity of enterprise resources, Large domestic investment will affect the level of foreign investment of enterprises, which will make enterprises lose the opportunity to participate in foreign direct investment. On the other hand, corporate executives are subject to a higher degree of government administrative restrictions, which allows the government to communicate its policy on 
foreign direct investment to corporate decision-makers, and decision-makers will use this policy as the primary reference [11].

Non-state-owned enterprises mainly display market logic, clear property rights, single business objectives, and the pursuit of maximizing corporate profits. Non-stateowned enterprises, as an important force to promote my country's economic development, have been actively implementing the "going out" strategy in recent years. Based on the domestic basis, they expand foreign direct investment, use multiple investment methods such as cross-border mergers and acquisitions, joint ventures, etc. to combine their own operating advantages with various advantages in the host country market to form their own unique integration advantages, which greatly improves the enterprises' Competitiveness.

\section{Outward foreign direct investment (OFDI)}

The study found that China's OFDI development has its own unique model. Child \& Rodrigues believes that most of China's foreign investment decisions will succumb to the requirements of national will or macroeconomic interests, which is different from the goal of private companies to maximize profits, resulting in their investment flows will not be based entirely on the general laws of international capital flows, Which in turn will cause China's OFDI decision-making to be different from other countries. On the basis of reading and summarizing the research of scholars, this article classifies foreign direct investment behavior as follows:

\section{- $\quad$ Resource-seeking OFDI.}

The resource-seeking OFDI guarantees the effective supply of domestic resources by controlling foreign resources [12]. This behavior has a certain national strategic intention. Resource-seeking OFDI requires investment approval of the home country and host country, and carries certain political risks, legal risks, cultural risks, and market risks. In addition, the host country' $\mathrm{s}$ review standards are ambiguous, the actual implementation process is highly operable, the approval is strict and the cycle is long, and the requirements for the scale, capability and risk tolerance of the enterprise are high. These requirements have hit the enterprise' $s$ resource-seeking type to a certain extent. The motivation of OFDI [13].

- Technology-seeking OFDI.

Technology-seeking companies track the latest trends in the industry by establishing R\&D centers in technologically advanced regions or acquiring host country R\&D teams in the form of mergers and acquisitions, understanding competitors in technology-intensive regions, accumulating human resources, and improving their comprehensive capabilities [14][15][16]. Technology-seeking OFDI can increase an enterprise's internal capabilities, enhance its core competitiveness, promote its industrial upgrading, and give it a comparative advantage in internationalization [17].

- $\quad$ Market-seeking OFDI.

Market-seeking OFDI refers to companies seeking overseas markets and selling excess products abroad to increase their profits [18]. The market-seeking OFDI must consider the host country' $\mathrm{s}$ market size, competitors' situation, 
consumption level, consumer preferences, as well as the company' s own size and flexibility.

\section{The Relationships between enterprise ownership and performance}

How are the performance of state-owned enterprises' OFDI affected? In the process of OFDI of state-owned enterprises, the Chinese government often provides support or guarantee at the level of policies and systems. State-owned enterprises enjoy policy benefits such as subsidies, credit, taxation, and supervision. However, state-owned enterprises also face a lot of problems when making OFDI: firstly, state-owned enterprises need to respond to the national call and consider the overall welfare of society, including diplomatic, economic, energy security and resource security factors, and secondly consider their own profits [19]; Secondly, the lack of crisis awareness and competition concept, and the lack of clear purpose and orientation of state-owned enterprises' direct investment abroad, which led to the state-owned enterprises' investment in the host country's economic environment, legal environment and investment prior to their direct investment abroad The lack of sufficient inspection and evaluation of information such as the legal system, to a certain extent, may inhibit the improvement of the operating performance of state-owned enterprises. Finally, the state encourages state-owned enterprises to tap and utilize the innovative resources of developed countries with a more positive attitude. Because of this, overseas mergers and acquisitions of state-owned enterprises are more likely to be resisted or obstructed by the host country [20][21].

What are the advantages and disadvantages of OFDI by non-state-owned enterprises? Non-state-owned enterprises with clear property rights have greater operational autonomy when making OFDI, and can make scientific investment decisions based on the interests of the enterprise and market-oriented. At the same time, less policy intervention is also conducive to exerting its internal advantages and realizing economies of scale. The main difficulties for non-state-owned enterprises are: First, non-state-owned enterprises lack financial support. The funds for a country's overseas investment mainly come from the country's National Export-Import Bank, while my country's Export-Import Bank loans mainly support overseas investment projects undertaken by large and medium-sized state-owned enterprises. Second, my country's non-state-owned enterprises are generally small in scale. According to statistics, $73 \%$ of private enterprises have annual sales of less than RMB 2 billion, of which $64 \%$ have a profit of less than RMB 100 million. However, in comparison, nonstate-owned enterprises have more advantages in OFDI than state-owned enterprises.

The analysis based on our data also supports our hypothesis: the performance of non-state-owned enterprises is higher than that of state-owned enterprises [22].

\section{The relationships between OFDI and enterprise performance}

As China's economy continues to develop, China's demand for resources is increasing, but domestic resource reserves are limited. After years of extensive mining, domestic resources have been unable to meet the needs of economic development (Ramasamy, 2012). Resource-seeking ODI is crucial to China's overall economic development. The 
probability that the market-seeking OFDI is subject to review by the host government is mainly determined by the willingness of the enterprise. This involves the company's preliminary investigation and evaluation of the host country's overall operating environment, the company's ability to withstand risks, and the company's expectations for market prospects, sales volume increases, marginal costs, and corporate profits. The market-seeking OFDI of enterprises mainly revolves around reducing costs and increasing profits for enterprises. Compared with resource-seeking OFDI, marketseeking companies perform better.

Two other assumptions:

- The technology-seeking OFDI has better performance than the resourceseeking OFDI.

- The market-seeking OFDI is better than the technology-seeking OFDI.

Data research results show that the impact is not significant.

\section{Conclusion}

By using the inter-provincial panel data of 571 listed enterprises from 2014 to 2017, this paper conducts an empirical study, and finds that:

1. in OFDI behavior, non-state-owned enterprises perform better than stateowned enterprises;

2. some Chinese enterprises will choose resource-seeking OFDI;

3. non-state-owned enterprises will choose market-seeking OFDI;

4. the performance of market-seeking OFDI is better than that of resourceseeking OFDI.

State-owned enterprises are much larger than non-state-owned enterprises in terms of enterprise size and financing level, and are more inclined to resource-seeking OFDI. Most non-state-owned enterprises have weak risk tolerance, and are more inclined to purchase and imitate technologies, and to carry out technology-seeking OFDI. In order to get rid of the disadvantage of partial saturation of the domestic market, non-stateowned enterprises will resort to OFDI to seek overseas markets and actively pursue market-seeking OFDI. In resource-seeking OFDI, Chinese enterprises encounter many uncertainties. For example, the government of the host country takes too long to review, leading to the high cost of waiting time for enterprises, and missing the opportunity of resource production, resulting in the high production cost of enterprises. The cost of resources acquired by enterprises through OFDI is generally high, and resource-seeking OFDI has little impact on the improvement of enterprise performance. The performance of market-seeking OFDI is higher than that of resource-seeking OFDI.

This paper studies the relationship among enterprise ownership, OFDI behavior and OFDI performance from the perspective of institutional logic, and selects data from the enterprise micro level as the measurement sample. Academically, it complements the research in this field. In practice, it provides reference Suggestions for promoting Chinese enterprises to better adapt to the international environment, better conduct OFDI behaviors, and improve the success rate and efficiency of OFDI. 


\section{Acknowledgement}

The authors gratefully acknowledge a grant from Guangdong Provincial Educational Science Planning Project "School-enterprise Collaborative Education Model and Mechanism Innovation of Applied Talent Cultivation-Research Based on Stakeholder Perspective" (2017GXJK153).

\section{References}

[1] Xin Qing, Liu Weiquan. Role of ofdi in global value chain upgrading, International Economic Cooperation, 2011(2):91-94.

[2] N.N., China's ofdi statistical bulletin, 2016.

[3] WTO.World Trade Report 2017[R].WTO Publishing, 2017.

[4] Xie Kang, On the causes and measures of China's ofdi, World economic research, 1994(2):40-44.

[5] Song Ligang, Yang Jidong, Zhang Yongsheng. Ofdi and institutional reform of Chinese state-owned enterprises, International economic review, 2013 (1) :75-86.

[6] Ye Yajie, Research on ofdi of Chinese enterprises from the perspective of institutional distance, Henan social sciences, 2017, 25 (6) : 112-118.

[7] Wu Liang, Research on the relationship between network capability, organizational learning and the upgrading of OEM enterprises. Jiangxi university of finance and economics, 2017:40-45.

[8] Xin Qing, Liu Weiquan. Role of ofdi in global value chain upgrading, International economic cooperation, 2011(2):91-94.

[9] Jiang Nengpeng, Chen Jingwei, FDI, global value chain embedding and total factor productivity, Journal of hebei university of economics and trade, 2019.

[10] Li-Jun Xia. Yi-Qiang Fang, Government control on Environmental management and corporate Performance, Economic Research, 2005(5).

[11] He Fan, Yao Zhizhong. China's outbound investment: theory and problems, Shanghai university of finance and economics press, Shanghai, 2013.

[12] Liu Lia, He Yanlin, Wang Zhaofei, et al. Will financing constraints affect Chinese companies' ofdi? Financial research, 2015(8):124-140.

[13] Yang Pingli, Zhang Jianmin, Empirical research on the development of export enterprises as a determinant of ofdi from the perspective of enterprise heterogeneity, Business review of nantah university, 2015(3):49-68.

[14] Zhao Chenyu, Li Xuesong, Ofdi and enterprise technological innovation -- empirical research based on micro data of Chinese listed companies, International trade issues, 2017(06):107-119.

[15] Cheng Yukun, Financing constraints and the binary margin of multi-product export enterprises: an analysis based on Chinese enterprises, Southern economics, 2014,V32(10):63-81.

[16] R. Friedland, J.W. Mohr, H. Roose et al. The institutional logics of love: measuring intimate life, Theory \& Society, 2014, 43(3-4):333-370.

[17] M. Suchman, Managing legitimacy: Strategic and institutional approaches, Academy of Management Review, 1995, 20(3):571-610.

[18] P.J. Dimaggio, W. Powell, Institutional isomorphism and collective rationality in organizational fields, American Sociological Review, 1983, 48(2):147-160.

[19] W.R. Scott, Institutions and Organizations, Sage, Thousand Oaks, 1995.

[20] Du Yunzhou, You Shuyang, Frontier research on institutional logic and institutional diversity and future research prospects, Foreign economy and management, 2013, 35(12):2-10.

[21] P.H. Thornton, W. Ocasio, Institutional Logics, The Sage handbook of organizational instututionalism, 2008, 840: 99-129.

[22] R. Friedland, R.R., Alford Bringing Society Back In: Symbols, Practices, and Institutional Contradictions, Journal of Chicago University of Chicago, 1991. 